\title{
Skeletal mineralogy of geniculate corallines: providing context for climate change and ocean acidification research
}

\author{
C. J. Williamson ${ }^{1,2, *}$, J. Najorka1 ${ }^{1}$ R. Perkins ${ }^{2}$, M. L. Yallop ${ }^{3}$, J. Brodie ${ }^{1}$ \\ ${ }^{1}$ Department of Life Sciences, The Natural History Museum, Cromwell Road, London SW7 5BD, UK \\ ${ }^{2}$ School of Earth and Ocean Sciences, Cardiff University, Park Place, Cardiff CF10 3YE, UK \\ ${ }^{3}$ School of Biological Sciences, University of Bristol, Bristol BS8 1UG, UK
}

\begin{abstract}
Marine species depositing high-magnesium $(\mathrm{Mg})$ calcite $\left(>8 \% \mathrm{MgCO}_{3}\right.$ ) are projected to be among the first to show response to the impacts of climate change, i.e. increased sea surface temperature (SST) and ocean acidification (OA), given the increasing solubility of calcite in seawater with increasing $\mathrm{Mg}$ content. Temperature is a major driver of $\mathrm{Mg}$ incorporation into the skeletons of calcifying macroalgae, and thus climate change may induce deposition of more soluble calcite, exacerbating responses to OA. Assessment of the skeletal Mg content of 3 geniculate, calcifying species of the genera Corallina and Ellisolandia (Rhodophyta, Corallinales), $C$. officinalis, C. caespitosa and E. elongata, sampled during 2012-2013 in the UK intertidal, demonstrated the existence of seasonal cycles in skeletal Mg. Seasonal cycles in skeletal Mg were also observed for herbarium collections of the Natural History Museum (British Museum), London, sampled during the recent past (1850-2010). Comparative sampling across a northeastern Atlantic latitudinal transect (Iceland to northern Spain) indicated a decreasing Mg content with increasing latitude for present-day C. officinalis, and relationships between SST and Corallina $\mathrm{Mg}$ content $\left(\mathrm{r}^{2}=0.45-0.76\right)$ demonstrated the dominant influence of temperature on Corallina species skeletal mineralogy. Corallina and Ellisolandia species show lower absolute values of Mg content (0.11-0.16 mol\% Mg/Ca), and smaller variation with change in SST $(0.0028-0.0047 \mathrm{~mol} \% \mathrm{Mg} / \mathrm{Ca}$ ${ }^{\circ} \mathrm{C}^{-1}$ ), than other temperate calcifying macroalgae studied to date. Over the period 1850-2010, no change in the magnitude of $\mathrm{Mg}$ incorporation by $C$. officinalis was detected in herbarium samples. However, the strong relationship between SST and Mg content indicates that projected increases in SST by 2100, which are far greater than temperature increases that occurred between 1850-2010, could have substantial impact on geniculate coralline algae skeletal mineralogy, and must be considered synergistically with the effects of OA.
\end{abstract}

KEY WORDS: Corallina officinalis · Ellisolandia elongata $\cdot$ Corallina caespitosa $\cdot$ Climate change · Ocean acidification $\cdot \mathrm{Mg} / \mathrm{Ca}$ ratio $\cdot$ Skeletal mineralogy

\section{INTRODUCTION}

Since 1961, an excess of $80 \%$ of climate changerelated atmospheric heating has been absorbed by the world's oceans, resulting in an increase in the global average sea surface temperature (SST) of

\footnotetext{
*Corresponding author: williamsoncj@cardiff.ac.uk
}

$0.65^{\circ} \mathrm{C}$ between 1850 and 2005, according to the Intergovernmental Panel on Climate Change (IPCC) Fourth Assessment Report (Solomon et al. 2007). Concomitantly, ocean acidification (OA), the increasing acidity of the world's oceans attributed to uptake of anthropogenic $\mathrm{CO}_{2}$, has decreased the global

() The authors 2014. Open Access under Creative Commons by Attribution Licence. Use, distribution and reproduction are unrestricted. Authors and original publication must be credited. 
average ocean $\mathrm{pH}$ by 0.1 relative to pre-industrial values, resulting in a $26 \%$ increase in hydrogen ion $\left(\mathrm{H}^{+}\right)$concentration and reduced biologically available carbonate ions $\left(\mathrm{CO}_{3}{ }^{2+}\right.$ ) (Feely et al. 2004, Doney 2006, Hoegh-Guldberg et al. 2007, Rhein et al. 2013). By 2100, climate change models predict increased global ocean average SST ranging from $+0.6^{\circ} \mathrm{C}$ to more than $+3.0^{\circ} \mathrm{C}$ and a further decrease in average ocean $\mathrm{pH}$ of 0.13 to 0.42 under IPCC Representative Concentration Pathways (RCPs) 2.6 and 8.5, respectively (Collins et al. 2013).

Varying responses of marine species to increases in SST and OA have been reported, with numerous studies predicting adverse effects of OA on those species that deposit calcium carbonate $\left(\mathrm{CaCO}_{3}\right)$ as shells or skeletal structures (e.g. Gao et al. 1993, 2009, Langdon et al. 2000, Langdon \& Atkinson 2005, Anthony et al. 2008, Kuffner et al. 2008, Zheng \& Gao 2009, Cohen et al. 2009, Kleypas \& Yates 2009, Dias et al. 2010, Dupont et al. 2010, Gao \& Zheng 2010, Diaz-Pulido et al. 2012, Hofmann et al. 2012). Within the marine environment, different biogenic polymorphs of $\mathrm{CaCO}_{3}$ are deposited, each with different solubility in seawater (Ries 2011). Aragonite, the polymorph deposited by, for example, scleractinian coral species, is more soluble than pure calcite; however, the solubility of calcite increases with increasing magnesium ion $\left(\mathrm{Mg}^{2+}\right)$ content substituting for calcium $\left(\mathrm{Ca}^{2+}\right)$ ions (Andersson et al. 2008, Ries 2010, 2011). High-Mg biogenic calcite (i.e. greater than $8-12 \% \mathrm{MgCO}_{3}$ ) is more soluble than aragonite in seawater (Andersson et al. 2008). Species depositing this polymorph are therefore likely to be more susceptible to the initial effects of OA (Gao et al. 1993, Morse et al. 2007, Kuffner et al. 2008, Ries et al. 2009, Ries 2010, Lombardi et al. 2011).

Red coralline macroalgae (Corallinales, Rhodophyta) are the most common high-Mg calcite producers, along with benthic foraminifera, bryozoans and echinoderms (Andersson et al. 2008). Coralline macroalgae comprise both geniculate genera (i.e. jointed or articulated), and non-geniculate genera, which are either encrusting, e.g. crustose coralline algae, or free-living nodules, known as rhodoliths or maerl (Irvine \& Chamberlain 1994, Nelson 2009). Coralline algae have limited control over their calcification processes in that they are able to specify deposition of the calcite polymorph, as opposed to aragonite, but are unable to actively control the degree of $\mathrm{Mg}$ incorporation into their calcite skeletons (Ries 2010). Variation in Mg content is controlled by mechanisms including the $\mathrm{Mg} / \mathrm{Ca}$ ratio of seawater, which is only applicable over geological timescales (Ries 2006,2010 ), and factors that influence growth rate, e.g. light availability (Andersson et al. 2008), the seawater carbonate saturation state (Andersson et al. 2008, Ries 2011, Egilsdottir et al. 2013), salinity (Kamenos et al. 2012) and temperature (Kamenos et al. 2008, Kuffner et al. 2008, Ries 2010, 2011). For example, observed decreases in the $\mathrm{Mg}$ content of calcite in coralline algae with increasing latitude have been attributed to concomitant decreases in light, seawater carbonate saturation and temperature (Chave 1954, Mackenzie et al. 1983, Andersson et al. 2008).

Within latitudes, temperature is the dominant influence on the skeletal Mg content of present-day coralline macroalgae (Kamenos et al. 2008). For example, seasonal cycles in $\mathrm{Mg}$ incorporation in the rhodolith species Lithothamnion glaciale (12.9$24.6 \mathrm{~mol} \% \mathrm{MgCO}_{3}$ range) and Phymatolithon calcareum (14.7-23.8 mol\% $\mathrm{MgCO}_{3}$ range) show a strong positive regression $\left(\mathrm{r}^{2}=0.88-0.96\right)$ with in situ seawater temperatures, with a change of 1.26 and $1.19 \mathrm{~mol} \% \mathrm{MgCO}_{3}{ }^{\circ} \mathrm{C}^{-1}$ for the 2 species, respectively (Kamenos et al. 2008).

Given the positive relationship between SST and Mg incorporation into calcite (Kamenos et al. 2008), climate change-associated elevations in SST may lead to an increase in the relative proportion of more soluble calcite forms in coralline macroalgae, exacerbating the impacts of OA, as hypothesized for the bryozoan Myriapora truncata (Lombardi et al. 2011). Conversely, however, decreases in seawater carbonate saturation owing to OA itself may serve to decrease $\mathrm{Mg}$ content in coralline macroalgae. In the rhodolith Neogoniolithon sp., calcite $\mathrm{Mg} / \mathrm{Ca}$ ratio decreased from 0.249 to 0.197 with a decrease in seawater aragonite saturation state from 2.5 to 0.7 (Ries 2011), and a decreased mol\% Mg/Ca was observed in new structures formed by the geniculate Ellisolandia elongata during elevated $p \mathrm{CO}_{2}$ incubations $(0.177$ $\pm 0.002)$ compared to ambient conditions $(0.190 \pm$ 0.003) (Egilsdottir et al. 2013).

Multi-stressor studies examining the simultaneous impacts of increased SST and OA on the skeletal mineralogy of coralline macroalgae are currently lacking. When available, contextual interpretation of such results will depend on a clear understanding of the natural variation in the present-day carbonate skeletal mineralogy of these species, and its relationship with environmental conditions, in particular SST (Medakovic et al. 1995, Kamenos et al. 2008, Smith et al. 2012). In addition, given that present-day climate conditions, i.e. post-industrialization, are already sig- 
nificantly shifted in comparison to pre-industrial times, examination of the skeletal mineralogy of coralline macroalgae to date, where possible, will further add to our capacity to predict and interpret potential future changes.

This study therefore assessed the present-day and recent-past (i.e. 1850-2010) variation in skeletal Mg incorporation in species of the cosmopolitan geniculate coralline genera Corallina and Ellisolandia, which are extremely ecologically important (Nelson 2009), yet relatively understudied in relation to climate change and OA. Erect, turfing species of Corallina and Ellisolandia are near-ubiquitous in temperate intertidal and subtidal environments (Smith et al. 2012), providing habitat for numerous small invertebrates, shelter via their physical structure from environmental stresses associated with intertidal habitats, and a substratum for the settlement of macro- and microalgae (Nelson 2009, Smith et al. 2012). Given these attributes, geniculate corallines are considered important autogenic ecosystem engineers (Jones et al. 1994, Nelson 2009), and as such, potential impacts of climate change-driven increases in SST and/or OA on these species could have serious implications for temperate coastal ecosystems and species therein (Hofmann et al. 2012).

The aims of the present study were to (1) quantify the present-day temporal and spatial patterns in $\mathrm{Mg} / \mathrm{Ca}$ ratios of C. officinalis and C. caespitosa from the UK intertidal over a seasonal cycle; (2) examine interspecific variation in $\mathrm{Mg} / \mathrm{Ca}$ ratios between $C$. officinalis, C. caespitosa and Ellisolandia elongata; (3) examine intraspecific variation in Corallina $\mathrm{Mg} / \mathrm{Ca}$ ratios over small (within-site) to large (across latitudes) spatial scales; (4) assess the recent-past (ca. 1850-2010) patterns in UK C. officinalis $\mathrm{Mg} / \mathrm{Ca}$ ratios from herbarium collections of the Natural History Museum (British Museum), London; (5) examine the relationship between Corallina $\mathrm{Mg} / \mathrm{Ca}$ ratios and $\mathrm{SST}_{\text {; }}$ and (6) use these relationships to produce projections of Corallina skeletal mineralogy under future ocean conditions.

\section{MATERIALS AND METHODS}

\section{Seasonal sampling}

To examine present-day seasonal, within-site, and interspecific patterns in Corallina skeletal $\mathrm{Mg} / \mathrm{Ca}$ ratios $(\mathrm{mol} \% \mathrm{Mg} / \mathrm{Ca}), 12$ samples each of $C$. officinalis and C. caespitosa were collected haphazardly by hand from within rock pools at each shore height where they occurred (Table 1) during December 2011 and March, June, September and December 2012 from Combe Martin, North Devon, UK (Fig. 1). To ensure sampling of discrete individuals, samples were collected at least $30 \mathrm{~cm}$ away from each other. Each sample consisted of a discrete basal portion and attached upright fronds. Sample replication of $n=12$ was selected by plotting $\mathrm{n}$ against cumulative $\mathrm{mol} \% \mathrm{Mg} / \mathrm{Ca}$ variance. Cumulative variance decreased and saturated at $\mathrm{n}=12-15$ samples for both species (data not shown). Following collection, samples were mounted onto herbarium sheets using site seawater collected on the day of sampling, dried in a press, and stored on herbarium sheets until processing.

Table 1. Sampling site details (see also Fig. 1). SST: sea surface temperature. C.: Corallina; E.: Ellisolandia

\begin{tabular}{|c|c|c|c|c|c|c|c|c|}
\hline Site & Location & $\begin{array}{l}\text { Sampling } \\
\text { months }\end{array}$ & $\begin{array}{l}\text { Avg. }(\min -\max ) \\
\operatorname{SST}\left({ }^{\circ} \mathrm{C}\right)\end{array}$ & $\begin{array}{c}\text { Shore height } \\
\text { sampled }\end{array}$ & $\begin{array}{l}\text { Shore height } \\
\text { relative to chart } \\
\text { datum }(\mathrm{m})\end{array}$ & $\begin{array}{l}\text { Species } \\
\text { present }\end{array}$ & $\begin{array}{c}\text { Estimated } \\
\text { pool volume } \\
\left(\mathrm{m}^{3}\right)\end{array}$ & $\begin{array}{l}\text { Estimated } \\
\text { pool depth } \\
\quad(\mathrm{cm})\end{array}$ \\
\hline $\begin{array}{l}\text { Combe } \\
\text { Martin, UK }\end{array}$ & $\begin{array}{c}51^{\circ} 12^{\prime} 31^{\prime \prime} \mathrm{N}, \\
4^{\circ} 2^{\prime} 19^{\prime \prime} \mathrm{W}\end{array}$ & $\begin{array}{c}\text { Dec } 2011 \\
\text { Mar } 2012 \\
\text { Jun } 2012 \\
\text { Sep } 2012 \\
\text { Dec } 2012\end{array}$ & $\begin{array}{c}9.9(8.9-11.4) \\
8.5(7.0-10.2) \\
14.2(12-15.5) \\
16.4(13.4-17.6) \\
9.9(8.9-11.4)\end{array}$ & $\begin{array}{l}\text { Upper } \\
\text { Middle } \\
\text { Lower }\end{array}$ & $\begin{array}{l}+5.5 \\
+5.0 \\
+3.5\end{array}$ & $\begin{array}{l}\text { C. officinalis } \\
\text { C. caespitosa } \\
\text { C. caespitosa } \\
\text { C. officinalis }\end{array}$ & $\begin{array}{l}0.09 \\
0.25\end{array}$ & $\begin{array}{l}2-4 \\
500\end{array}$ \\
\hline $\begin{array}{l}\text { Wembury } \\
\text { Point, UK }\end{array}$ & $\begin{array}{c}50^{\circ} 18^{\prime} 53^{\prime \prime} \mathrm{N} \\
4^{\circ} 4^{\prime} 58^{\prime \prime} \mathrm{W}\end{array}$ & Jun 2012 & $13.8(11.8-16.9)$ & $\begin{array}{l}\text { Upper } \\
\text { Lower }\end{array}$ & $\begin{array}{l}+4.0 \\
+2.3\end{array}$ & $\begin{array}{l}\text { C. officinalis } \\
\text { C. officinalis } \\
\text { E. elongata }\end{array}$ & $\begin{array}{l}0.25 \\
0.25\end{array}$ & $\begin{array}{l}500 \\
500\end{array}$ \\
\hline $\begin{array}{l}\text { Porlákshöfn, } \\
\text { Iceland }\end{array}$ & $\begin{array}{l}63^{\circ} 53^{\prime} 36^{\prime \prime} \mathrm{N}, \\
21^{\circ} 23^{\prime} 45^{\prime \prime} \mathrm{W}\end{array}$ & Jul 2012 & $11.7(10.1-13.6)$ & Lower & +1.5 & C. officinalis & 1.5 & 500 \\
\hline $\begin{array}{l}\text { A Coruña, } \\
\text { Spain }\end{array}$ & $\begin{array}{l}43^{\circ} 22^{\prime} 13^{\prime \prime} \mathrm{N}, \\
8^{\circ} 24^{\prime} 54^{\prime \prime} \mathrm{W}\end{array}$ & Oct 2012 & $17.4(16.2-19.7)$ & Lower & +2.0 & $\begin{array}{l}\text { C. officinalis } \\
\text { E. elongata }\end{array}$ & 0.125 & 500 \\
\hline
\end{tabular}




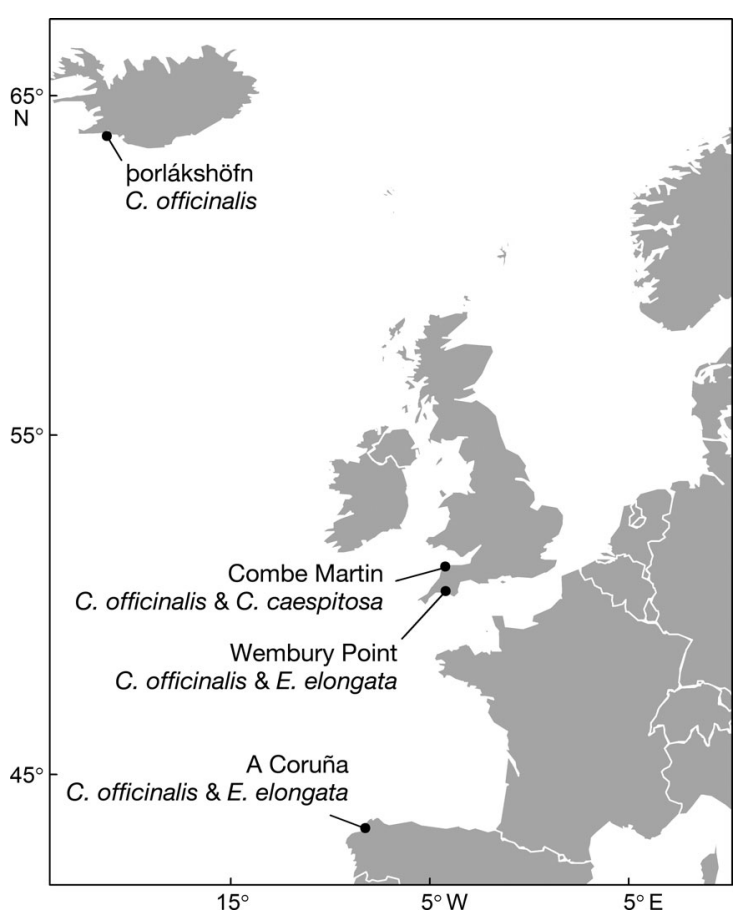

Fig. 1. Study sites in the NE Atlantic indicating Corallina and Ellisolandia species present at each site (see also Table 1)

\section{Comparative sampling}

To examine spatial variation and interspecific differences in mol\% Mg/Ca between UK sites, Corallina officinalis and Ellisolandia elongata were sampled from Wembury Point during June 2012 (12 individual plants per species and shore height present; Table 1) for comparison to Combe Martin data. To examine intraspecific variation in $\mathrm{mol} \% \mathrm{Mg} / \mathrm{Ca}$ over a northeastern Atlantic latitudinal transect, $C$. officinalis was sampled ( $\mathrm{n}=12$ individual plants) from Iceland and northern Spain (Table 1), allowing differences to be assessed over 1418 miles $(2282 \mathrm{~km})$, with Combe Martin and Wembury Point located 542 and 480 miles ( 872 and $772 \mathrm{~km}$ ) north from the northern Spain site, respectively (Fig. 1). Additionally, E. elongata was sampled from northern Spain for interspecific comparisons. Species identification was achieved by amplification of the cox 1 gene region and comparison with published sequences as per Walker et al. (2009).

\section{Herbarium collections}

C. officinalis from UK sites were selected to examine recent-past patterns in Corallina $\mathrm{mol} \% \mathrm{Mg} / \mathrm{Ca}$, as they represented the largest collection of Corallina species held in the algal herbarium collections of the Natural History Museum (BM), London. These collections span from ca. 1850 to 2010, and are predominantly from donations made by individual collectors, not as established regular sampling initiatives, making samples over this period spatially and temporally heterogeneous, and lacking replication (Table S1 in the Supplement at www.int-res.com/articles/suppl/ m513p071_supp.pdf). In total, 112 C. officinalis samples were selected from the herbarium collections for use in the current study. Sub-sampling for analysis was conducted as detailed in the following section.

\section{Sample processing}

In order to examine the skeletal $\mathrm{Mg}$ content most representing the time of collection during the present study, whilst allowing sufficient material for X-ray diffraction (XRD) analysis (see next section), the apical intergeniculum was sampled from 10-15 branches of each Corallina and Ellisolandia sample and pooled to comprise 1 sample for XRD analysis (Fig. 2). Growth of Corallina species is mostly restricted to a finite group of elongating and dividing apical cells (Colthart \& Johansen 1973). Little data exists on the growth rates of geniculate corallines, but Colthart \& Johansen (1973) reported rates of $2.2 \mathrm{~mm}$ per month

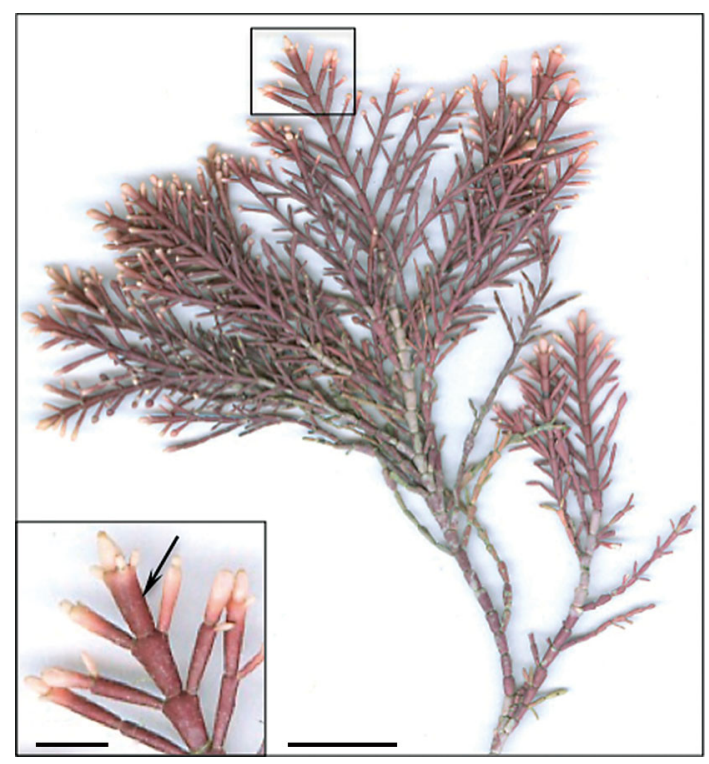

Fig. 2. Representative frond of Corallina officinalis collected from Combe Martin, UK (scale bar $=0.5 \mathrm{~cm}$ ). Inset: apical region of frond branch (scale bar $=1 \mathrm{~mm}$ ); arrow: apical intergenicula sampled for X-ray diffraction analysis 
for C. officinalis at $12-18^{\circ} \mathrm{C}$, corresponding to the production of a single $1 \mathrm{~mm}$ long intergeniculum per $12 \mathrm{~d}$, and Hofmann et al. (2012) reported relative growth rates of $1.97 \pm 0.15 \%$ fresh weight $\mathrm{d}^{-1}$ for the same species grown at $15^{\circ} \mathrm{C}$ with $50 \mu \mathrm{mol}$ photons $\mathrm{m}^{-2} \mathrm{~s}^{-1}$ light intensity. Mol\% $\mathrm{Mg} / \mathrm{Ca}$ reported by the present study therefore likely represent $\mathrm{Mg}$ incorporation over approximately the previous $12 \mathrm{~d}$ before the time of sampling during periods of SST ranging from $12-18^{\circ} \mathrm{C}$, and longer periods, given presumably lower growth rates, below these temperatures.

\section{$\mathrm{X}$-ray diffraction analysis}

All XRD analyses were conducted in the Mineralogy Department of The Natural History Museum, London. Samples were ground with a mortar and pestle and suspended in acetone (ca. 1:20 sample: acetone suspension). A few drops of the sampleacetone suspension were placed onto a single crystal sapphire substrate (zero-background holder). The dried samples were analysed using an Enraf-Nonius PDS120 diffractometer equipped with a primary Germanium (111) monochromator and an INEL $120^{\circ}$ curved position sensitive detector (PSD). Operating conditions for the Co source were $40 \mathrm{kV}$ and $40 \mathrm{~mA}$. The horizontal slit after the monochromator was set to $0.14 \mathrm{~mm}$ to confine the incident beam to pure Co $\mathrm{Ka}_{1}$ radiation. The vertical slit was set to $5 \mathrm{~mm}$.

Samples were measured in asymmetric flat-plate reflection geometry. Diffracted X-ray intensities were simultaneously collected over a 2 -Theta range of $120^{\circ}$ without angular movement of tube, sample or detector position. The tilting angle between incident beam and sample surface was kept constant at $6^{\circ}$ and the sample was rotated during the measurements to improve particle counting statistics. Angular linearity of the PSD was calibrated using $\mathrm{Y}_{2} \mathrm{O}_{3}$ as external standard. A full 2-Theta linearization of the PSD was performed with a least-squares cubic spline function.

The $\mathrm{Mg}$ content of the calcite skeletons of the Corallina and Ellisolandia species was derived from the position of the $d_{104}$ reflection in the XRD pattern. All data of the present study fall into a compositional interval between 10 and $17 \mathrm{~mol} \% \mathrm{Mg}$. A linear relationship between $\mathrm{d}_{104}$ value and $\mathrm{Mg}$ concentration of skeletal magnesian calcites was first reported by Chave (1952) over the range $2-16 \mathrm{~mol} \% \mathrm{Mg}$. Considering compositions between 0 and $20 \mathrm{~mol} \% \mathrm{Mg}$ of biogenic and inorganic magnesian calcites, Mackenzie et al. (1983) concluded the $d_{104}$ trend is equivalent to a straight line from calcite to disordered dolomite or magnesite. Therefore, the present study derived the molar $\mathrm{Mg}$ content on the $\mathrm{Ca}$ site of magnesian calcites, i.e. the substitution of $\mathrm{Ca}$ ions for $\mathrm{Mg}$ ions in the crystal lattice of the calcite, using the linear relationship in Eq. (1):

$$
\text { Mol\% Mg }=\frac{\mathrm{d}_{104}^{\text {calcite }}-\mathrm{d}_{104}^{\text {Mg-calcite (sample) }}}{\mathrm{d}_{104}^{\text {calcite }}-\mathrm{d}_{104}^{\text {magnesite }}}
$$

where data for calcite and magnesite were taken from well-characterized standards of the National Bureau of Standards (PDF-2 database from International Centre for Diffraction Data; reference codes calcite [5-586] and magnesite [8-479]). Calculated $\mathrm{d}_{104}$ trendlines from Eq. (1) and an overall fit of 3 synthetic magnesian calcite studies (Goldsmith et al. 1961, Bischoff et al. 1983, Mackenzie et al. 1983) showed only minor differences in the compositional range between 0 and $20 \mathrm{~mol} \% \mathrm{Mg}$. Deviations for a given $\mathrm{d}_{104}$ value were generally below $0.1 \mathrm{~mol} \% \mathrm{Mg}$.

\section{Predictive models}

To examine the relationship between SST and skeletal Mg incorporation by Corallina species, present-day and recent-past derived $\mathrm{mol} \% \mathrm{Mg} / \mathrm{Ca}$ ratios were regressed against locally reported SSTs which were obtained from the website 1 of the Centre for Environment, Fisheries and Aquaculture Science (CEFAS). For Combe Martin seasonal data, linear regression analysis was performed against monthly average SST recorded from 1992 to 2008 at CEFAS Stn 27 , located at Ilfracombe $\left(51^{\circ} 20^{\prime} 51^{\prime \prime} \mathrm{N}\right.$, $4^{\circ} 12^{\prime} 67^{\prime \prime} \mathrm{W}$ ), approximately $8.8 \mathrm{~km}$ from Combe Martin. For mol\% Mg/Ca derived from herbarium samples, average SST data were retrieved for the month of sample collection from the nearest CEFAS station to the point of collection recorded (Table S1 in the Supplement). Given the non-continuous nature of CEFAS SST data throughout time, SST values for 45 of 112 herbarium data points were available for regression analysis. Changes in the $\mathrm{mol} \% \mathrm{Mg} / \mathrm{Ca}$ ${ }^{\circ} \mathrm{C}^{-1}$ of Corallina species were derived from linear regression equations to SST. Regression equations derived for Combe Martin seasonal data were plotted using the monthly average SST data reported for the entire year from CEFAS Stn 27, to demonstrate the complete $\mathrm{mol} \% \mathrm{Mg} / \mathrm{Ca}$ seasonal cycle for $C$. officinalis and C. caespitosa. Additionally, pooled

\footnotetext{
$\underline{1}_{\text {www.cefas.defra.gov.uk/our-science/observing-and-modelling/ }}$ monitoring-programmes/sea-temperature-and-salinity-trends/ station-positions-and-data-index.aspx
} 
monthly herbarium mol\% Mg/Ca data ( $\mathrm{n}=112$ ) were modeled using a sine function regression (using Sigmaplot v.10 software) fitted to the apparent sine waveform of the data as a function of time.

\section{Statistical analysis}

Prior to all statistical analyses, normality of data was tested using the Anderson-Darling test, and homogeneity of variance using Levene's test (significant differences from normality and homogeneity of variance were taken at the $5 \%$ significance level). All data were normally distributed and demonstrated homogeneous variance, or were transformed to meet these criteria as described below. All analyses were performed using Minitab v.14 software.

\section{Seasonal sampling}

To examine differences in mol\% $\mathrm{Mg} / \mathrm{Ca}$ between sampling months, shore heights and species (C. officinalis and C. caespitosa) at Combe Martin, a nested ANOVA was performed with the factors 'Month', 'Shore height' and 'Species', with Species nested within Shore height, and the interaction terms 'Month $\times$ Shore height' and 'Month $\times$ Species'. Post hoc Tukey HSD analysis was used to examine significant differences highlighted by ANOVA analyses.

\section{Comparative sampling}

As no significant difference in C. officinalis mol\% $\mathrm{Mg} / \mathrm{Ca}$ were evident between upper and lower shore Combe Martin or Wembury Point during June 2012, data from both shore heights were pooled per site for inter-site comparison. To examine differences in $C$. officinalis mol\% Mg/Ca collected from Combe Martin and Wembury Point during June 2012 and from Iceland during July 2012, a 1-way ANOVA was performed with the factor 'Site'. To examine differences in $\mathrm{mol} \% \mathrm{Mg} / \mathrm{Ca}$ between $C$. officinalis sampled in Combe Martin during September 2012 and northern Spain during October 2012, a $t$-test was performed with the factor 'Site'. Interspecific differences in $\mathrm{mol} \% \mathrm{Mg} / \mathrm{Ca}$ of $C$. officinalis and E. elongata were examined by $t$-test comparison with the factor 'Species' between C. officinalis and E. elongata collected from lower shore Wembury Point during June 2012, and between $C$. officinalis and E. elongata collected from northern Spain during October 2012.
Herbarium collections

Statistical differences in $\mathrm{mol} \% \mathrm{Mg} / \mathrm{Ca}$ of herbarium data were examined using ANCOVA on squareroot transformed data with the factors 'Location', 'Year' and 'Month' (covariate within 'Year'). The factor 'Location' was derived by categorizing herbarium samples into the county of collection.

\section{RESULTS}

\section{Seasonal sampling}

There was a significant difference in the mol\% $\mathrm{Mg} / \mathrm{Ca}$ of Corallina officinalis and C. caespitosa from Combe Martin in relation to 'Month' $\left(F_{4,220}=174.61\right.$,

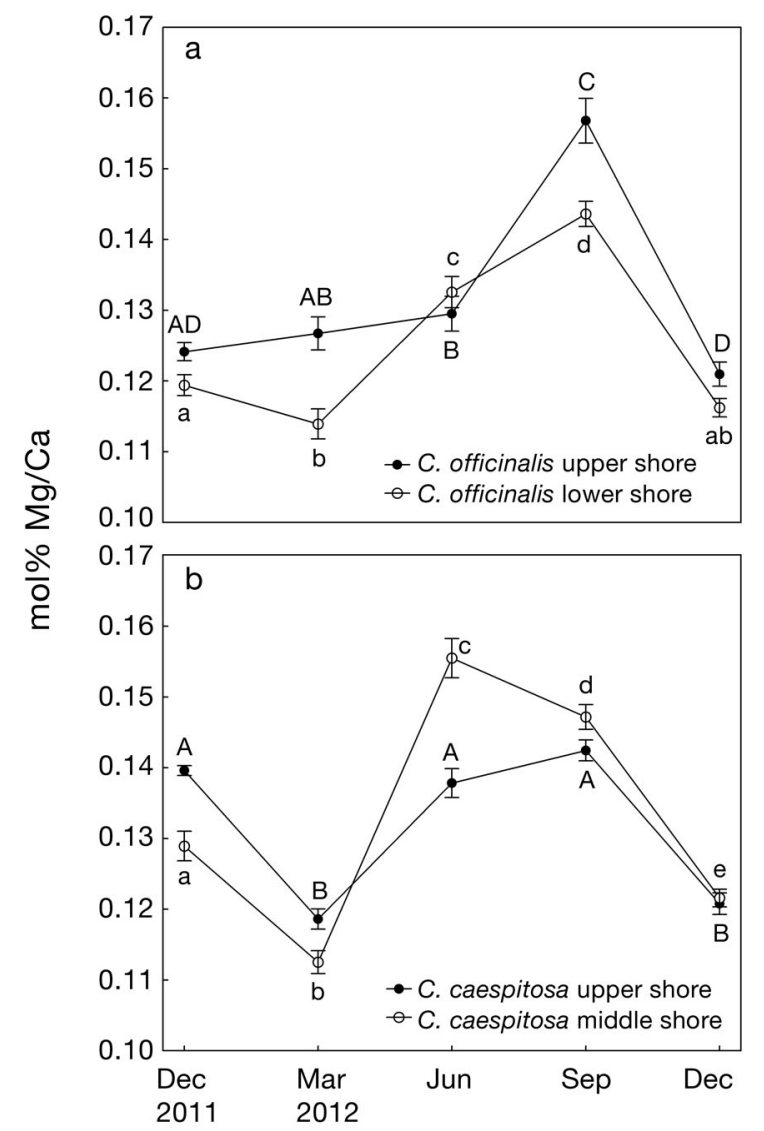

Fig. 3. Seasonal variation in mol\% $\mathrm{Mg} / \mathrm{Ca}$ of (a) Corallina officinalis from upper and lower shore, and (b) C. caespitosa from upper and middle shore of Combe Martin (mean $\pm \mathrm{SE}$, $\mathrm{n}=12$ ). Letters denote homogeneous subsets as determined by post hoc Tukey HSD analysis (at significance $\alpha=0.05$ ). Upper case letters refer to upper shore data and lower case letters refer to lower or middle shore data, respectively. Actual values (avg., min/max) are provided in Table S2 in the Supplement at www.int-res.com/articles/suppl/m513 p071_supp.pdf 
$\mathrm{p}<0.0001$ ) (Fig. 3a,b). Highest $\mathrm{mol} \% \mathrm{Mg} / \mathrm{Ca}$ was recorded for both upper (mean \pm SE: $0.156 \pm 0.003$ ) and lower $(0.143 \pm 0.001)$ shore $C$. officinalis and upper shore $C$. caespitosa $(0.142 \pm 0.001)$ during September 2012, while middle shore C. caespitosa demonstrated maximal values during June 2012 $(0.155 \pm 0.002)$. Lowest $\mathrm{mol} \% \mathrm{Mg} / \mathrm{Ca}$ were recorded during March 2012 for upper $(0.118 \pm 0.001)$ and middle $(0.112 \pm 0.001)$ shore $C$. caespitosa, and lower shore $C$. officinalis $(0.113 \pm 0.002)$, while upper shore C. officinalis demonstrated minimal values during December $2012(0.120 \pm 0.001)$. Homogeneous subsets determined from post hoc Tukey HSD analysis are demonstrated in Fig. 3a,b.

Though significant interaction was observed between 'Month' and 'Species' $\left(F_{4,220}=19.92, \mathrm{p}<\right.$ 0.0001 ), no significant interspecific difference in mol\% Mg/Ca was observed between Combe Martin C. officinalis and C. caespitosa. Similarly, no significant difference in $\mathrm{mol} \% \mathrm{Mg} / \mathrm{Ca}$ was observed in

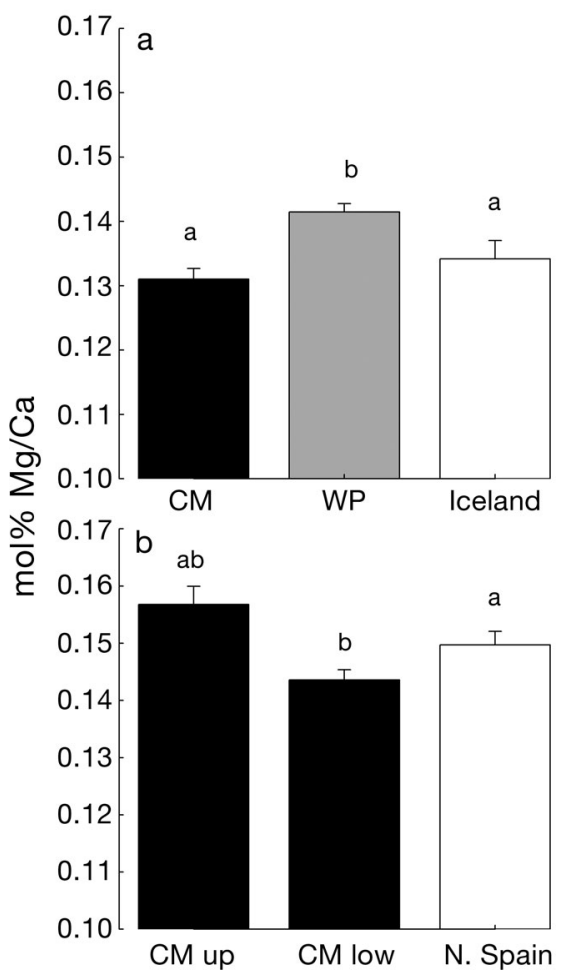

Fig. 4. (a) Corallina officinalis $\mathrm{mol} \% \mathrm{Mg} / \mathrm{Ca}$ collected June 2012 from Combe Martin (CM) and Wembury Point (WP) (mean $\pm \mathrm{SE}, \mathrm{n}=24$ ), and July 2012 from lower shore Porlákshöfn, Iceland (mean $\pm \mathrm{SE}, \mathrm{n}=12$ ). (b) C. officinalis $\mathrm{mol} \%$ $\mathrm{Mg} / \mathrm{Ca}$ (mean $\pm \mathrm{SE}, \mathrm{n}=12$ ) collected during September from Combe Martin upper (CM up) and lower (CM low) shore, and October from lower shore A Coruña, northern Spain. Letters indicate homogeneous subsets as determined from post hoc Tukey HSD analysis (at significance $\alpha=0.05$ ) relation to 'Shore height', though significant interaction was apparent between 'Month' and 'Shore height' $\left(F_{8,220}=14.22, \mathrm{p}<0.0001\right)$. For $C$. officinalis, upper shore samples demonstrated higher mol\% $\mathrm{Mg} / \mathrm{Ca}$ than lower shore during all months except June 2012, whereas C. caespitosa from the mid shore had the highest mol\% $\mathrm{Mg} / \mathrm{Ca}$ in the summer, but had lower ratios than upper shore $C$. caespitosa collected in the winter and spring.

\section{Comparative sampling}

A significant difference in C. officinalis $\mathrm{mol} \%$ $\mathrm{Mg} / \mathrm{Ca}$ was observed in relation to 'Site' $\left(F_{2,59}=9.44\right.$, $\mathrm{p}<0.001$ ), with post hoc Tukey HSD analysis demonstrating significantly decreased values in C. officinalis collected from Iceland during July 2012 and Combe Martin during June 2012 in comparison to Wembury Point, though no significant difference between Combe Martin and Iceland $\mathrm{mol} \% \mathrm{Mg} / \mathrm{Ca}$ was apparent (Fig. 4a). Samples collected from lower shore Combe Martin in September 2012 demonstrated significantly lower $\mathrm{mol} \% \mathrm{Mg} / \mathrm{Ca}$ in comparison to samples collected from northern Spain in October $2012\left(\mathrm{~T}_{22}=-2.08, \mathrm{p}<0.05\right)$, though there was no significant difference between upper shore Combe Martin and northern Spain samples (Fig. 4b). No interspecific differences were observed between the $\mathrm{mol} \% \mathrm{Mg} / \mathrm{Ca}$ of $C$. officinalis and E. elongata from either Wembury Point or northern Spain (Table S2 in the Supplement at www.int-res.com/ articles/suppl/m513p071_supp.pdf).

\section{Herbarium collections}

No significant difference in $\mathrm{mol} \% \mathrm{Mg} / \mathrm{Ca}$ of $C$. officinalis apical tips was observed in relation to 'Location' or 'Year', though a significant difference was observed in relation to 'Month' $\left(F_{10,111}=7.46, \mathrm{p}<\right.$ 0.001 ), with 'Month' showing significant covariance within 'Year' $(p<0.05)$. Average monthly mol\% Mg/ Ca of all herbarium data are presented in Fig. 5, demonstrating an apparent seasonal temporal pattern of $\mathrm{mol} \% \mathrm{Mg} / \mathrm{Ca}$ as a function of month, effectively with summer maxima and late winter/spring minima.

\section{Temperature relationships}

Significant linear relationships were identified between local SST and mol\% Mg/Ca of Combe Martin 


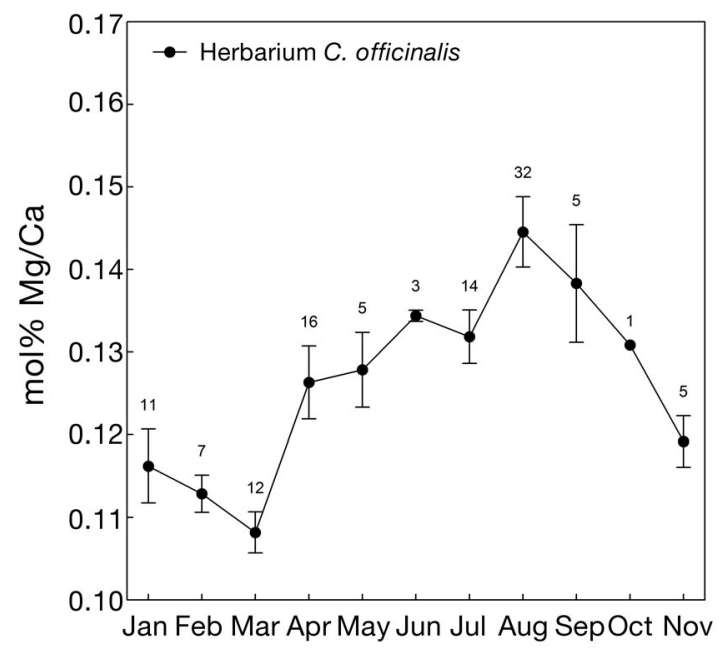

Fig. 5. Herbarium Corallina officinalis average monthly $\mathrm{mol} \% \mathrm{Mg} / \mathrm{Ca} \pm \mathrm{SE}$ (monthly average across all years, see Table S1 in the Supplement at www.int-res.com/articles/ suppl/m513p071_supp.pdf). Numbers represent sample size of the respective month

seasonally sampled C. officinalis (both upper and lower shore) and C. caespitosa (both upper and middle shore) (Fig. 6a,b, Table 2A). Based on these relationships, changes in $\mathrm{Mg}$ concentration of 0.0035 and $0.0037 \mathrm{~mol} \% \mathrm{Mg} / \mathrm{Ca}{ }^{\circ} \mathrm{C}^{-1}$ were determined for upper and lower shore $C$. officinalis, respectively, and 0.0028 and $0.0047 \mathrm{~mol} \% \mathrm{Mg} / \mathrm{Ca}{ }^{\circ} \mathrm{C}^{-1}$ for C. caespitosa upper and middle shore, respectively. Significant linear relationships were also identified between local SST and C. officinalis $\mathrm{mol} \% \mathrm{Mg} / \mathrm{Ca}$ determined from $\mathrm{n}=$ 45 herbarium samples (Fig. 6c, Table 2B), with a change in $\mathrm{mol} \% \mathrm{Mg} / \mathrm{Ca}$ of $0.0036^{\circ} \mathrm{C}^{-1}$ determined.

$\mathrm{Mol} \% \mathrm{Mg} / \mathrm{Ca}$ were predicted using CEFAS SST data from Stn 27 for each month for both C. officinalis and C. caespitosa from Combe Martin (Fig. 7a). In addition, all herbarium data $(\mathrm{n}=112)$ grouped into month of collection demonstrated a clear sine waveform function over time, with all equation parameters given significant at $p<0.001$ (Fig. $7 b$, Table 2B).

\section{DISCUSSION}

\section{Present-day mol\% Mg/Ca cycles}

Corallina species in the northeastern Atlantic have clear seasonal cycles in skeletal Mg incorporation, as demonstrated by seasonal variability in $\mathrm{mol} \% \mathrm{Mg} / \mathrm{Ca}$ of present-day $C$. officinalis and C. caespitosa recorded during this study. These findings are in line with previous work that have demonstrated season-
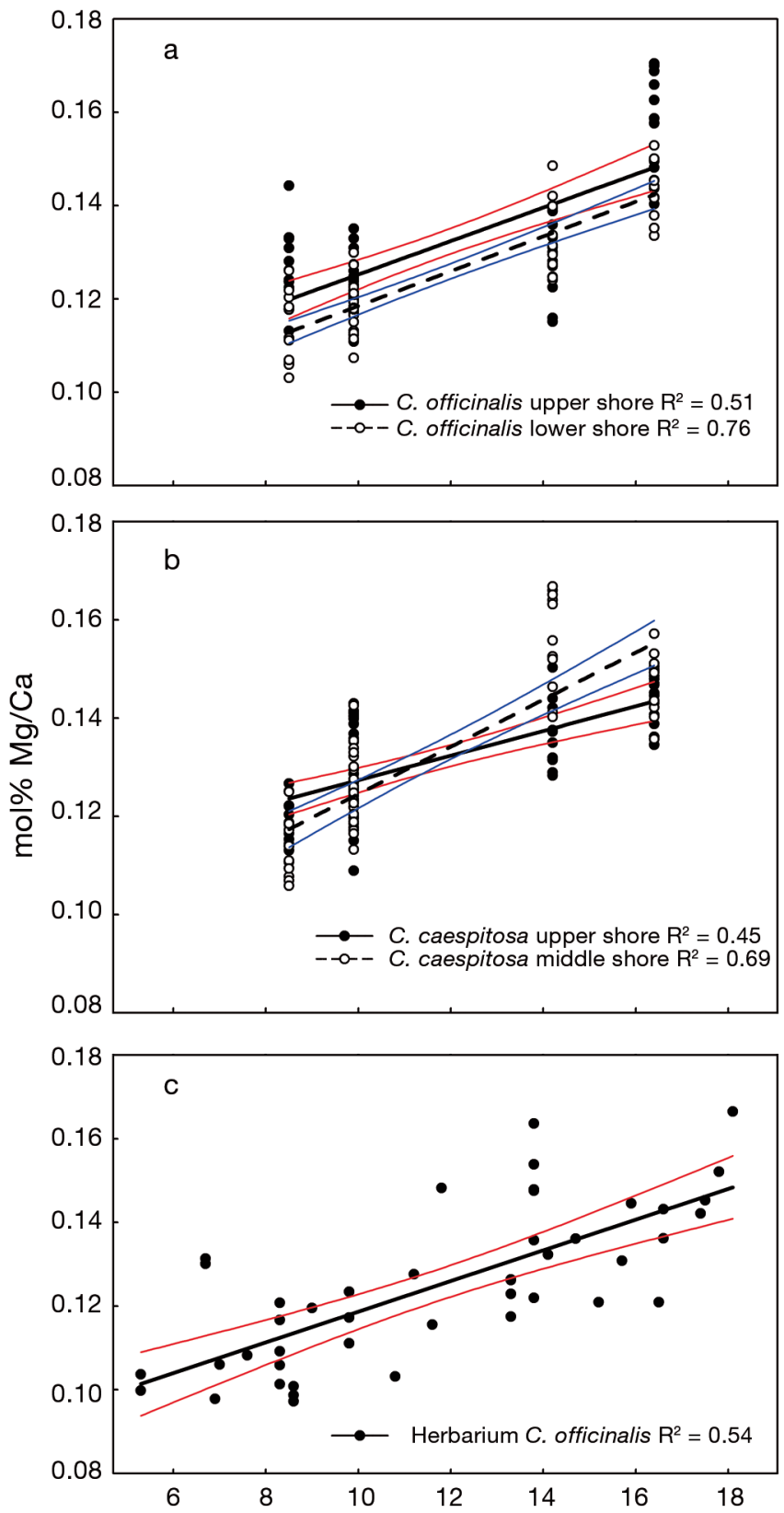

Fig. 6. Mol\% Mg/Ca-temperature relationships for (a) Corallina officinalis collected from upper and lower shore and (b) C. caespitosa collected from upper and middle shore, from Combe Martin, and (c) herbarium C. officinalis (see Table 2A for relationship equations). All regressions were significant at $\mathrm{p}<0.0001$ (Table 2A) and are displayed with $95 \%$ confidence intervals (red and blue lines) of predictions made from least-squares regressed linear relationships

ally cyclic patterns of $\mathrm{Mg} / \mathrm{Ca}$ ratios in rhodoliths (Kamenos et al. 2008), corals (Mitsuguchi et al. 1996) and other calcifying species (Chave 1954), and support the assertion that the Corallinaceae are a group with consistently high Mg content (ca. $10 \mathrm{~mol} \%$ or more) (Vinogradov 1953). 
Table 2. (A) Mol\% Mg/Ca-temperature relationships for Corallina officinalis and C. caespitosa from Combe Martin, and herbarium C. officinalis matched to sea surface temperature (SST). (B) Mol\% Mg/Ca-month relationship for all herbarium C. officinalis samples, where month is represented by values 1 to 11 (January to November) (see also Figs. 6 \& 7). na: not applicable

\begin{tabular}{|c|c|c|c|c|c|c|c|c|}
\hline $\begin{array}{l}\text { A } \\
\text { Species }\end{array}$ & $\begin{array}{l}\text { Shore } \\
\text { height }\end{array}$ & Relationship $(y=m x+c)$ & $\mathrm{R}^{2}$ & $\mathrm{~m} \mathrm{SE}$ & c SE & $\mathrm{r}$ & $\mathrm{p}$ & $\mathrm{n}$ \\
\hline \multirow[t]{2}{*}{ C. officinalis } & Upper & $\mathrm{Mol} \% \mathrm{Mg} / \mathrm{Ca}=0.00358 \mathrm{SST}+0.0894$ & 0.51 & \pm 0.0004542 & \pm 0.005522 & 0.71 & $<0.0001$ & 60 \\
\hline & Lower & $\mathrm{Mol} \% \mathrm{Mg} / \mathrm{Ca}=0.00372 \mathrm{SST}+0.0813$ & 0.76 & \pm 0.0002699 & \pm 0.003281 & 0.87 & $<0.0001$ & 60 \\
\hline \multirow[t]{2}{*}{ C. caespitosa } & Upper & $\mathrm{Mol} \% \mathrm{Mg} / \mathrm{Ca}=0.00286 \mathrm{SST}+0.1022$ & 0.45 & \pm 0.0003628 & \pm 0.004410 & 0.67 & $<0.0001$ & 60 \\
\hline & Middle & $\mathrm{Mol} \% \mathrm{Mg} / \mathrm{Ca}=0.00479 \mathrm{SST}+0.0766$ & 0.69 & \pm 0.0004138 & \pm 0.005030 & 0.83 & $<0.0001$ & 60 \\
\hline $\begin{array}{l}\text { C. officinalis } \\
\text { (herbarium) }\end{array}$ & na & $\mathrm{Mol} \% \mathrm{Mg} / \mathrm{Ca}=0.00367 \mathrm{SST}+0.0819$ & 0.54 & \pm 0.0005073 & \pm 0.006247 & 0.74 & $<0.0001$ & 45 \\
\hline B & & & & & & & & \\
\hline Species & \multicolumn{2}{|c|}{ Relationship $\left(y=y_{0}+b \sin (2 \pi(x / c)+d)\right.$} & $\mathrm{R}^{2}$ & SE & $\mathrm{r}$ & $\mathrm{p}$ & $\mathrm{n}$ & \\
\hline $\begin{array}{l}\text { C. officinalis } \\
\text { (herbarium) }\end{array}$ & \multicolumn{2}{|c|}{$\begin{array}{l}\mathrm{Mol} \% \mathrm{Mg} / \mathrm{Ca}= \\
0.1270+0.0145 \sin [2 \pi(\text { Month/11.2423) }+3.5493]\end{array}$} & 0.47 & $\begin{array}{r}y_{0} \pm 0.0013 \\
b \pm 0.0015 \\
c \pm 0.9944 \\
d \pm 0.3211\end{array}$ & 0.68 & $<0.0001$ & 112 & \\
\hline
\end{tabular}

Concentrations and seasonal ranges of $\mathrm{Mg}$ in geniculate Corallina and Ellisolandia species are towards the lower end of those reported for other coralline macroalgae from similar geographic regions. For example, Combe Martin C. officinalis $\mathrm{Mg}$ content (expressed as $\mathrm{mol} \% \mathrm{MgCO}_{3}$ ) ranged from approximately $10-17 \mathrm{~mol}^{\mathrm{O}} \mathrm{MgCO}_{3}$ and C. caespitosa from $10-16 \mathrm{~mol}^{2} \mathrm{MgCO}_{3}$. These concentrations and ranges are noticeably lower than those reported for the rhodoliths Lithothamnion glaciale (12.9-24.6 mol\% $\mathrm{MgCO}_{3}$ ) and Phymatolithon calcareum (14.7-23.8 mol\% $\mathrm{MgCO}_{3}$ ) from Scotland (Kamenos et al. 2008), though are in the same range as those reported for the geniculate coralline E. elongata from France $(0.177 \pm 0.002 \mathrm{~mol} \% \mathrm{Mg} / \mathrm{Ca})$ (Egilsdottir et al. 2013).

Biogenic Mg-calcites have been demonstrated to go through a maximum solubility at approximately $24 \mathrm{~mol} \% \mathrm{MgCO}_{3}$, with the most insoluble $\mathrm{Mg}$-calcite containing about $2 \mathrm{~mol} \% \mathrm{MgCO}_{3}$ (Plummer \& Mackenzie 1974). Given this increasing solubility of calcite with increasing $\mathrm{Mg}$ content, variation in skeletal mineralogy between coralline species has been suggested to impact their vulnerability to OA (Gao et al. 1993, Morse et al. 2007, Andersson et al. 2008, Kuffner et al. 2008, Ries et al. 2009, Ries 2010, Lombardi et al. 2011, Smith et al. 2012). In this regard, northeastern Atlantic species of the genera Corallina and Ellisolandia may demonstrate reduced susceptibility to the impacts of OA on skeletal growth and dissolution in comparison to other high-Mg calcitedepositing coralline species, in particular rhodoliths, from similar geographic regions. The seasonal range

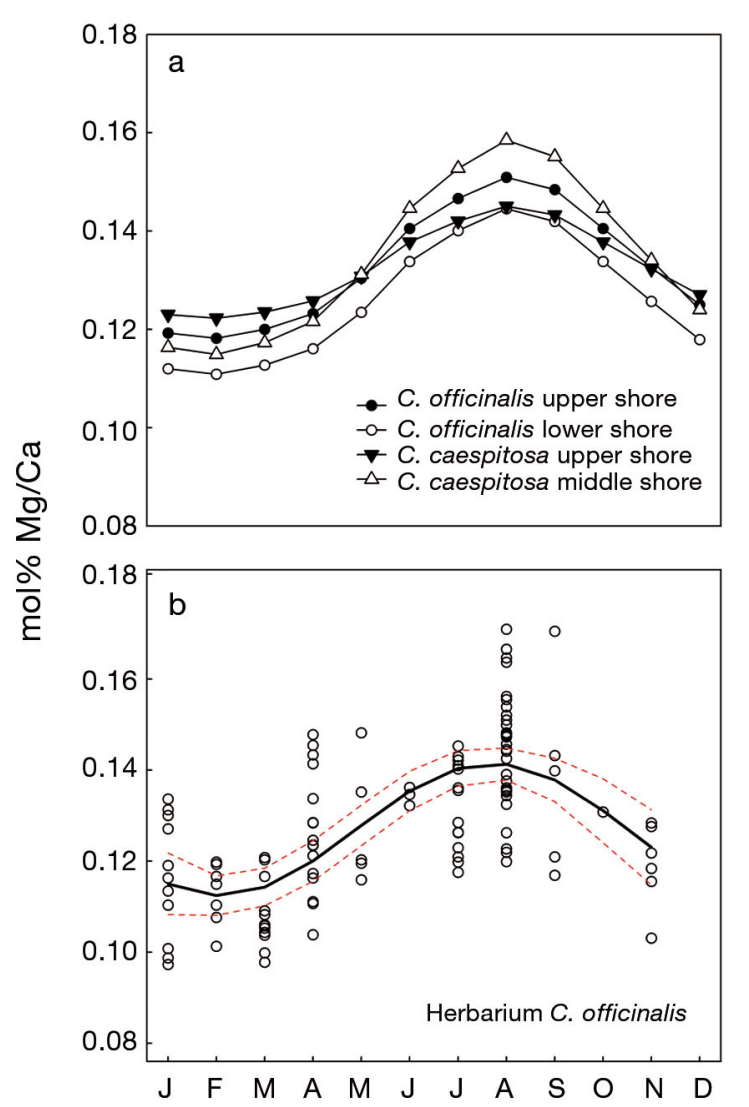

Fig. 7. (a) Predicted seasonal cycles in $\mathrm{mol} \% \mathrm{Mg} / \mathrm{Ca}$ of Corallina officinalis upper and lower shore, and C. caespitosa upper and middle shore, from Combe Martin, calculated using average monthly sea surface temperature (SST) reported from CEFAS Stn 27 and linear regression equations shown in Table 2A. (b) Herbarium C. officinalis mol\% $\mathrm{Mg} / \mathrm{Ca}(\mathrm{n}=112)$ with fitted sine waveform function in relation to month, showing $95 \%$ confidence intervals (dashed red lines) (see Table 2B for model equation) 
of Corallina Mg content reported here (approximately $0.11-0.16 \mathrm{~mol} \% \mathrm{Mg} / \mathrm{Ca}$ ) would correspond to a solubility product range (the equilibrium constant for a solid substance dissolving in an aqueous solution) of approximately -7.95 to $-7.69\left(\log \mathrm{K}\right.$ at $25^{\circ} \mathrm{C}$ and 0.98 bar $\mathrm{CO}_{2}$ ) based on Plummer \& Mackenzie (1974, their Table 3). For comparison, P. calcareum of Kamenos et al. (2008) would have a seasonal solubility product range of approximately -7.65 to -7.15 , the less negative values indicating increased solubility. This supports recent work that has demonstrated differential susceptibility of rhodolith and crustose coralline algae to OA conditions in comparison to geniculate coralline species (Noisette et al. 2013).

\section{Temperature relationships and inter/intra-specific mol\% Mg/Ca patterns}

Significant positive relationships identified between the $\mathrm{mol} \% \mathrm{Mg} / \mathrm{Ca}$ of $C$. officinalis and C. caespitosa and local SST $\left(\mathrm{R}^{2}=0.45-0.76\right.$ across our data; Fig. 6) highlight that under present climatic conditions, $\mathrm{Mg}$ incorporation by Corallina species is closely related to ambient seawater temperature. This is in agreement with data for rhodolith species from a similar geographic region (Kamenos et al. 2008), which have been highlighted as robust Mgpalaeotemperature proxies (Kamenos et al. 2009), and several marine calcifying species from numerous regions (Chave 1954). For example, Chave (1954) observed that in all groups of calcitic organisms where sufficient data are available, a linear or near-linear relationship exists between skeletal Mg content and the water temperature in which the organisms grew.

While strong $\mathrm{Mg}$-temperature relationships have been identified in numerous studies, Mg content is known also to be a function of growth rate, which is affected by several other abiotic parameters (Moberly 1968, Andersson et al. 2008, Ries 2010, 2011). For marine macroalgae, temperature and irradiance are 2 fundamental parameters controlling productivity, growth and distribution (Luning 1990, Lobban \& Harrison 1994). For calcifying species, carbonate chemistry also plays a crucial role in regulating calcification and thus growth processes (Andersson et al. 2008, Ries 2010, Egilsdottir et al. 2013). In intertidal habitats, temperature, irradiance and carbonate chemistry are interdependent, showing covariance over both long (i.e. seasonal) and short (i.e. diurnal) time periods (Ganning 1971, Truchot \& Duhamel-Jouve 1980, Morris \& Taylor 1983). While our data indicate a significant relationship between
Corallina skeletal Mg concentrations and SST, we cannot rule out the potential influence of other factors, e.g. irradiance, on $\mathrm{Mg}$ incorporation via effects to growth. Multifactorial laboratory incubations with manipulation of temperature, irradiance and carbonate chemistry are required to disentangle the individual roles of these factors.

Interspecific vital effects on $\mathrm{Mg}$ incorporation were found by the present study to be lacking or weak within the genus Corallina and between species of Corallina and Ellisolandia (previously all members of Corallina), as per the conclusions of Ries (2010). Different Corallina and Ellisolandia species sampled simultaneously from the same location within sites showed no significant difference in $\mathrm{mol} \% \mathrm{Mg} / \mathrm{Ca}$, while intraspecific differences in $\mathrm{mol} \% \mathrm{Mg} / \mathrm{Ca}$ were evident between both local sites (i.e. Combe Martin and Wembury Point) and across latitudes. At the small spatial scale (within sites), differences in skeletal Mg content can be related to position on shore and thus the varying influence of abiotic conditions. Regular, short-term fluctuations in temperature and other abiotic parameters (e.g. $p \mathrm{CO}_{2}, \mathrm{O}_{2}$, salinity, nutrient concentrations and irradiance) are experienced in intertidal rock pools inhabited by Corallina and Ellisolandia species (Ganning 1971, Daniel \& Boyden 1975, Morris \& Taylor 1983, Egilsdottir et al. 2013). During daylight emersion, irradiance drives increases in rock pool water temperature and photosynthetic utilization of $\mathrm{pCO}_{2}$, increasing $\mathrm{pH}$ and carbonate saturation due to effects on the carbonate chemistry equilibrium. During nighttime emersion, the opposite trends are apparent, with conditions potentially corrosive to calcite established through production of $p \mathrm{CO}_{2}$ by respiration processes and subsequent decreases in $\mathrm{pH}$ and carbonate saturation (Ganning 1971, Truchot \& Duhamel-Jouve 1980, Morris \& Taylor 1983). All of these dynamics may potentially impact geniculate coralline algae growth and calcification and thus $\mathrm{Mg}$ incorporation. In this regard, rock pools higher up a shore will experience longer periods of tidal emersion and therefore more extreme fluctuations in abiotic parameters, while lower shore rock pools, and the species therein, will be more influenced by ambient seawater conditions, e.g. SST. This trend is present in our data, whereby stronger regression of Corallina $\mathrm{mol} \% \mathrm{Mg} / \mathrm{Ca}$ to ambient SST is observed the further down a shore the species was collected. In addition, rock pool size may influence the degree of variability in abiotic conditions and thus skeletal Mg incorporation. Larger and deeper pools, for example, are known to have more stable conditions (Ganning 1971). The extremes 
in $\mathrm{mol} \% \mathrm{Mg} / \mathrm{Ca}$ of C. caespitosa collected from middle shore pools in comparison to upper pools likely relate to extremes in abiotic conditions experienced in these small/shallow middle shore pools (volume: ca. $0.09 \mathrm{~m}^{3}$, depth: ca. 2-4 $\mathrm{cm}$ ), in comparison to upper shore pools (ca. $40 \mathrm{~m}^{3}$ volume and $500 \mathrm{~cm}$ deep) (Table 1).

Across latitudes, intraspecific differences in C. officinalis $\mathrm{mol} \% \mathrm{Mg} / \mathrm{Ca}$ observed during summer and autumn may suggest that decreases in light, seawater carbonate saturation and temperature caused a decrease in $\mathrm{Mg}$ concentration in Corallina with increasing latitude (Chave 1954, Mackenzie et al. 1983, Andersson et al. 2008). This data should, however, be interpreted with caution, given the reduced sampling frequency in Iceland and northern Spain, and comparisons between different sampling months across latitudes. Additionally, samples of C. officinalis collected from Porlákshöfn in southwest Iceland may experience warmer conditions than implied by its location just south of the Arctic Circle. Despite the higher latitude, southwest coastal Iceland experiences a relatively moderate temperature regime due to the domination of the Irminger Current, a relatively warm offshoot from the North Atlantic Current, which results in summer SST over $10^{\circ} \mathrm{C}$ (Jiang et al. 2001). As such, 'latitudinal' differences in C. officinalis $\mathrm{mol} \% \mathrm{Mg} / \mathrm{Ca}$ may be reduced between e.g. southwest Iceland and the UK. To fully elucidate potential gradients in mol\% Mg/Ca of geniculate coralline algal species across latitudes, sampling over complete seasonal cycles is required at a range of latitudes.

\section{Recent past (i.e. 1850-2010) mol\% Mg/Ca cycles}

Despite the sporadic nature of herbarium collections, analysis of $C$. officinalis samples housed in the algal herbarium of the Natural History Museum (BM), London, enabled investigation into recent past cycles in $\mathrm{Mg}$ incorporation by Corallina species in the northeastern Atlantic, providing important information with regard to natural variability in Corallina skeletal mineralogy. Herbarium collections can thus represent an important resource for climate change and OA research (though see Huisman \& Millar 2013 for a discussion of herbarium limitations).

Notably, over the period $1850-2010$, no significant change in the $\mathrm{mol} \% \mathrm{Mg} / \mathrm{Ca}$ ratio of herbarium C. officinalis was detected during the present study, while within-year variability strongly reflected present-day seasonal cycles in skeletal Mg incorporation of Corallina species in terms of both absolute concen- trations and ranges. The influence of SST on Corallina Mg incorporation was also supported by significant positive regression of herbarium $C$. officinalis $\mathrm{mol} \% \mathrm{Mg} / \mathrm{Ca}$ cycles with locally reported SSTs. Our herbarium data thus confirm our present-day seasonal cycles in $\mathrm{mol} \% \mathrm{Mg} / \mathrm{Ca}$, strengthens the relationship between $\mathrm{Mg}$ incorporation and SST in Corallina species, and indicates that within the intertidal, such seasonal cycles have not changed significantly over the last ca. 150 yr (see below).

\section{Predictive models}

Corallina $\mathrm{mol} \% \mathrm{Mg} / \mathrm{Ca}$ and SST relationships enable projection of Corallina's skeletal mineralogy. Given the change in herbarium C. officinalis skeletal Mg content expected with temperature (Table 2B), we would expect an increase of approximately 0.23 $\mathrm{mol} \% \mathrm{MgCO}_{3}$ with the increase in global average SST of $0.65^{\circ} \mathrm{C}$ over the period $1850-2005$ caused by climate change (Solomon et al. 2007). Such an increase in $\mathrm{Mg}$ concentration was not observable in herbarium samples over the period 1850-2010, most likely owing to the sporadic nature and lack of replication of herbarium collections, and intraspecific variation in Corallina $\mathrm{Mg}$ concentration within and between sites. Additionally, simultaneous decreases in skeletal Mg content owing to decreased seawater carbonate saturation caused by concomitant OA over this period may have occurred (Ries 2011, Egilsdottir et al. 2013). However, had an increase of $0.23 \mathrm{~mol} \%$ $\mathrm{MgCO}_{3}$ occurred since 1850 in relation to increased SST, our data indicate that this would represent an increase of just $3.2 \%$ of the seasonal variation experienced by $C$. officinalis in the UK intertidal. It is therefore unlikely that cycles in intertidal C. officinalis $\mathrm{Mg}$ incorporation have been significantly impacted by climate change over the last $\sim 150 \mathrm{yr}$.

By 2100 , climate change models predict increased global ocean average SST ranging from $+0.6^{\circ} \mathrm{C}$ to more than $+3.0^{\circ} \mathrm{C}$ and a further decrease in average ocean $\mathrm{pH}$ of 0.13 to 0.42 under IPCC RCP2.6 and RCP8.5, respectively (Collins et al. 2013). A $3^{\circ} \mathrm{C}$ increase in SST could cause an increase in C. officinalis and C. caespitosa $\mathrm{Mg}$ content of approximately $1.1 \mathrm{~mol} \% \mathrm{MgCO}_{3}$, corresponding to approximately $32 \%$ of the seasonal variability in $\mathrm{Mg}$ concentration currently experienced by these species in the northeastern Atlantic. During periods of highest skeletal $\mathrm{Mg}$ content (i.e. August), Corallina mol\% $\mathrm{Mg} / \mathrm{Ca}$ would increase to approximately 0.15 , while in cooler months (i.e. February), mol\% Mg/Ca of approxi- 
mately 0.12 would be expected, giving a new solubility product range $\left(\log \mathrm{K}\right.$ at $25^{\circ} \mathrm{C}$ and 0.78 bar $\mathrm{CO}_{2}$ ) of approximately -7.74 to -7.93 (Plummer \& Mackenzie 1974). Although maximum Mg concentrations remain substantially less than observed in present-day rhodolith species (Kamenos et al. 2008), increases in the $\mathrm{Mg}$ content of Corallina may have impacts on skeletal growth and dissolution. This may be particularly important given Corallina's intertidal habitat, where rock pool $p \mathrm{CO}_{2}$ can naturally reach 1000 patm during dark tidal emersion periods due to respiration processes, causing significant decreases in rock pool carbonate saturation, and thus conditions corrosive to skeletal $\mathrm{CaCO}_{3}$ (Ganning 1971, Daniel \& Boyden 1975, Morris \& Taylor 1983, Egilsdottir et al. 2013).

Over the long term, reductions in seawater carbonate saturation owing to OA that will occur simultaneously with increases in SST may serve to decrease skeletal Mg concentrations, and therefore solubility/potential vulnerability to OA, and should also be considered when projecting future responses of calcifying organisms. For example, Egilsdottir et al. (2013) demonstrated an average reduction of 0.013 $\mathrm{mol} \% \mathrm{Mg} / \mathrm{Ca}$ in new structures formed by E. elongata in acidified conditions. This represents approximately $39 \%$ of the annual Mg variation experienced by present-day UK Corallina populations, of a similar magnitude to the increase projected with $+3^{\circ} \mathrm{C}$ SST. However, as multi-stressor incubation studies (i.e. increased temperature and decreased calcite saturation) have not been conducted with Corallina or Ellisolandia species to date, it is currently unknown which of these stressors (if either) will have a dominant influence on skeletal mineralogy and thus solubility under future oceanic conditions.

The potential impacts of climate change (increased SST and OA) on calcifying species of the genera $\mathrm{Co}$ rallina and Ellisolandia will be complex and should be addressed by multi-stressor future scenario incubations. Given the intertidal nature of these important ecosystem engineers (Nelson 2009), the results of such studies would benefit from knowledge of the natural variation in temperature and seawater carbonate chemistry currently experienced during periods of tidal emersion. Results of the present study demonstrate the present-day and recent-past skeletal mineralogy of temperate geniculate coralline algal species, the relationship between skeletal $\mathrm{Mg}$ content and SST, and place climate change and OAinduced changes in the skeletal mineralogy of these species into meaningful context with regard to present-day seasonal cycles.
Acknowledgements. We thank Ben Goss (Cardiff University, UK), Karl Gunnarsson (The Marine Institute, Reykjavik, Iceland) and Cesar Peteiro and Noemí Sánchez (Spanish Institute of Oceanography, Santander, Spain) for field assistance during the current project. We also thank Joe Wilbraham (Curator of Algae, the Natural History Museum, London) for assistance with herbarium collections.

\section{LITERATURE CITED}

Andersson A, Mackenzie F, Bates N (2008) Life on the margin: implications of ocean acidification on $\mathrm{Mg}$-calcite, high latitude and cold-water marine calcifiers. Mar Ecol Prog Ser 373:265-273

Anthony KRN, Kline DI, Diaz-Pulido G, Dove S, HoeghGuldberg O (2008) Ocean acidification causes bleaching and productivity loss in coral reef builders. Proc Natl Acad Sci USA 105:17442-17446

Bischoff WD, Bishop FC, Mackenzie FT (1983) Biogenically produced magnesian calcite, inhomogeneities in chemical and physical-properties comparison with synthetic phases. Am Mineral 68:1183-1188

Chave K (1952) A solid solution between calcite and dolomite. J Geol 60:190-192

Chave K (1954) Aspects of the biogeochemistry of magnesium. 1. Calcareous marine organisms. J Geol 62: 266-283

Cohen AL, McCorkle DC, de Putron S, Gaetani GA, Rose KA (2009) Morphological and compositional changes in the skeletons of new coral recruits reared in acidified seawater: Insights into the biomineralization response to ocean acidification. Geochem Geophys Geosyst 10: Q07005, doi:10.1029/2009GC002411

Collins M, Knutti R, Arblaster J, Dufresne JL and others (2013) Long-term climate change: projections, commitments and irreversibility. In: Stocker TF, Qin D, Plattner GK, Tignor M and others (eds) Climate change 2013: the physical science basis. Contribution of Working Group I to the Fifth Assessment Report of the Intergovernmental Panel on Climate Change. Cambridge University Press, Cambridge, p 1029-1136

> Colthart B, Johansen H (1973) Growth rates of Corallina officinalis (Rhodophyta) at different temperatures. Mar Biol 18:46-49

Daniel M, Boyden C (1975) Diurnal variations in physicochemical conditions within inter tidal rock pools. Field Stud 4:161-176

Dias BB, Hart MB, Smart CW, Hall-Spencer JM (2010) Modern seawater acidification: the response of foraminifera to high- $\mathrm{CO}_{2}$ conditions in the Mediterranean Sea. J Geol Soc Lond 167:843-846

$>$ Diaz-Pulido G, Anthony KRN, Kline DI, Dove S, HoeghGuldberg O (2012) Interactions between ocean acidification and warming on the mortality and dissolution of coralline algae. J Phycol 48:32-39

Doney SC (2006) The dangers of ocean acidification. Sci Am 294:58-65

Dupont S, Ortega-Martínez O, Thorndyke M (2010) Impact of near-future ocean acidification on echinoderms. Ecotoxicology 19:449-462

Egilsdottir H, Noisette F, Noël LMLJ, Olafsson J, Martin S (2013) Effects of $p \mathrm{CO}_{2}$ on physiology and skeletal mineralogy in a tidal pool coralline alga Corallina elongata. Mar Biol 160:2103-2112 
Feely RA, Sabine CL, Lee K, Berelson W, Kleypas J, Fabry VJ, Millero FJ (2004) Impact of anthropogenic $\mathrm{CO}_{2}$ on the $\mathrm{CaCO}_{3}$ system in the oceans. Science 305:362-366

Ganning B (1971) Studies on chemical physical and biological conditions in Swedish rockpool ecosystems. Ophelia 9:51-105

Gao K, Zheng Y (2010) Combined effects of ocean acidification and solar UV radiation on photosynthesis, growth, pigmentation and calcification of the coralline alga Corallina sessilis (Rhodophyta). Glob Change Biol 16: 2388-2398

Gao K, Aruga Y, Asada K, Ishihara T, Akano T, Kiyohara M (1993) Calcification in the articulated coralline alga Corallina pilulifera, with special reference to the effect of elevated $\mathrm{CO}_{2}$ concentration. Mar Biol 117:129-132

Gao K, Ruan Z, Villafan VE, Villefranche D (2009) Ocean acidification exacerbates the effect of UV radiation on the calcifying phytoplankter Emiliania huxleyi. Limnol Oceanogr 54:1855-1862

Goldsmith J, Graf D, Heard H (1961) Lattice constants of the calcium-magnesium carbonates. Am Mineral 46:453-457

> Hoegh-Guldberg O, Mumby PJ, Hooten AJ, Steneck RS and others (2007) Coral reefs under rapid climate change and ocean acidification. Science 318:1737-1742

> Hofmann LC, Yildiz G, Hanelt D, Bischof K (2012) Physiological responses of the calcifying rhodophyte, Corallina officinalis (L.), to future $\mathrm{CO}_{2}$ levels. Mar Biol 159: 783-792

Huisman J, Millar J (2013) Australian seaweed collections: use and misuse. Phycologia 52:2-5

Irvine LM, Chamberlain YM (eds) (1994) Seaweeds of the British Isles, Vol 1, Rhodophyta. Part 2B, Corallinales, Hildenbrandiales. HMSO, London

Jiang H, Seidenkrantz MS, Knudsen K, Eiríksson J (2001) Diatom surface sediment assemblages around Iceland and their relationships to oceanic environmental variables. Mar Micropaleontol 41:73-96

Jones C, Lawton J, Shachak M (1994) Organisms as ecosystem engineers. Oikos 69:373-386

Kamenos NA, Cusack M, Moore PG (2008) Coralline algae are global palaeothermometers with bi-weekly resolution. Geochim Cosmochim Acta 72:771-779

Kamenos NA, Cusack M, Huthwelker T, Lagarde P, Scheibling RE (2009) Mg-lattice associations in red coralline algae. Geochim Cosmochim Acta 73:1901-1907

Kamenos NA, Hoey TB, Nienow P, Fallick E, Claverie T (2012) Reconstructing Greenland ice sheet runoff using coralline algae. Geology 40:1095-1098

Kleypas JA, Yates KK (2009) Coral reefs and ocean acidification. Oceanography 22:108-117

> Kuffner IB, Andersson AJ, Jokiel PL, Rodgers KS, Mackenzie FT (2008) Decreased abundance of crustose coralline algae due to ocean acidification. Nat Geosci 1:114-117

Langdon $C_{1}$ Atkinson MJ (2005) Effect of elevated $p \mathrm{CO}_{2}$ on photosynthesis and calcification of corals and interactions with seasonal change in temperature/irradiance and nutrient enrichment. J Geophys Res 110:C09S07, doi: 10.1029/2004JC002576

Langdon C, Takahashi T, Sweeney C, Chipman D and others (2000) Effect of calcium carbonate saturation state on the calcification rate of an experimental coral reef. Global Biogeochem Cycles 14:639-654, doi:10.1029/ 1999GB001195

Lobban CS, Harrison PJ (1994) Seaweed ecology and physiology. Cambridge University Press, New York, NY
Lombardi C, Rodolfo-Metalpa R, Cocito S, Gambi MC, Taylor PD (2011) Structural and geochemical alterations in the Mg calcite bryozoan Myriapora truncata under elevated seawater $p \mathrm{CO}_{2}$ simulating ocean acidification. Mar Ecol 32:211-221

Luning K (1990) Seaweeds: their environment, biogeography and ecophysiology. John Wiley \& Sons, New York, NY

Mackenzie F, Bischoff W, Bishop F, Loijens M, SchoonMaker J, Wollast R (1983) Magnesian calcites: low temperature occurrence, solubility and solid-solution behavior. In: Reeder R (ed) Carbonates: mineralogy and chemistry. Mineralogical Society of America, Washington, DC, p 97-143

Medakovic D, Popovic S, Zavodnik N, Grzeta B, Plazonic M (1995) X-ray diffraction study of mineral components in calcareous algae (Corallinaceae, Rhodophyta). Mar Biol 122:479-485

Mitsuguchi T, Matsumoto E, Abe O, Uchida T, Isdale PJ (1996) $\mathrm{Mg} / \mathrm{Ca}$ thermometry in coral skeletons. Science 274:961-963

- Moberly R (1968) Composition of magnesian calcites of algae and pelecypods by electron microprobe analysis. Sedimentology 11:61-82

> Morris S, Taylor AC (1983) Diurnal and seasonal-variation in physicochemical conditions within intertidal rock pools. Estuar Coast Shelf Sci 17:339-355

> Morse JW, Arvidson RS, Lüttge A (2007) Calcium carbonate formation and dissolution. Chem Rev 107:342-381

> Nelson WA (2009) Calcified macroalgae-critical to coastal ecosystems and vulnerable to change: a review. Mar Freshw Res 60:787-801

> Noisette F, Egilsdottir H, Davoult D, Martin S (2013) Physiological responses of three temperate coralline algae from contrasting habitats to near-future ocean acidification. J Exp Mar Biol Ecol 448:179-187

> Plummer L, Mackenzie F (1974) Predicting mineral solubility from rate data: application to the dissolution of magnesian calcites. Am J Sci 274:61-83

Rhein M, Rintoul S, Aoki S, Campos E and others (2013) Observations: ocean. In: Stocker TF, Qin D, Plattner GK, Tignor $\mathrm{M}$ and others (eds) Climate change 2013: the physical science basis. Contribution of Working Group I to the Fifth Assessment Report of the Intergovernmental Panel on Climate Change. Cambridge University Press, Cambridge, p 255-316

Ries JB (2006) Mg fractionation in crustose coralline algae: geochemical, biological, and sedimentological implications of secular variation in the $\mathrm{Mg} / \mathrm{Ca}$ ratio of seawater. Geochim Cosmochim Acta 70:891-900

> Ries JB (2010) Review: geological and experimental evidence for secular variation in seawater Mg/Ca (calcitearagonite seas) and its effects on marine biological calcification. Biogeosciences 7:2795-2849

> Ries JB (2011) Skeletal mineralogy in a high- $\mathrm{CO}_{2}$ world. J Exp Mar Biol Ecol 403:54-64

Ries JB, Cohen AL, McCorkle DC (2009) Marine calcifiers exhibit mixed responses to $\mathrm{CO}_{2}$-induced ocean acidification. Geology 37:1131-1134

Smith AM, Sutherland JE, Kregting L, Farr TJ, Winter DJ (2012) Phylomineralogy of the coralline red algae: correlation of skeletal mineralogy with molecular phylogeny. Phytochemistry 81:97-108

Solomon S, Qin D, Manning M, Chen Z and others (eds) (2007) Climate change 2007: the physical science basis. 
Contribution of Working Group I to the Fourth Assessment Report of the Intergovernmental Panel on Climate Change. Cambridge University Press, Cambridge

Truchot JP, Duhamel-Jouve A (1980) Oxygen and carbon dioxide in the marine intertidal environment: diurnal and tidal changes in rockpools. Respir Physiol 39: 241-254

Vinogradov A (1953) Elementary composition of non-planktonic marine algae. Chapter II. In: Parr AE (ed) The elementary chemical composition of marine organisms.
Sears Foundation for Marine Research, New Haven, CT, p 17-129

Walker RH, Brodie J, Russell S, Irvine LM, Orfanidis S (2009) Biodiversity of coralline algae in the northeastern Atlantic including Corallina caespitosa. nov. (Corallinoideae, Rhodophyta). J Phycol 45:287-297

Zheng Y, Gao K (2009) Impacts of solar UV radiation on the photosynthesis, growth, and UV-absorbing compounds in Gracilaria lemaneiformis (Rhodophyta) grown at different nitrate concentrations. J Phycol 45:314-323

Submitted: December 4, 2013; Accepted: June 25, 2014 Proofs received from author(s): September 24, 2014
Editorial responsibility: Brian Helmuth, Nahant, Massachusetts, USA 